\title{
Comparison of motor strength and function in patients with Duchenne muscular dystrophy with or without steroid therapy
}

\author{
Samara Lamounier Santana Parreira, Maria Bernadete Dutra Resende, \\ Edmar Zanoteli, Mary Souza Carvalho, Suely Kazue Marie, \\ Umbertina Conti Reed
}

\begin{abstract}
Objective: To compare muscle strength (MS) and motor function in patients with Duchenne muscular dystrophy (DMD) receiving steroids for different times against the natural evolution of DMD described by Scott et al. Method: 90 patients with DMD (aged 5- 12 years), receiving steroids for one to seven years, were evaluated by Medical Research Council Scale (MRC) and Hammersmith motor ability score. The relation between MS and motor abilities measurement from our data and Scott's ones were ascertained statistically. Results: The relation between patient's age and Hammersmith scores revealed decrease of 0.76 point per year for age against decrease of 2.23 points on Scott's study. The relation between MRC scale and patient's age showed decrease of 0.80 point per year of age against decrease of 3.65 points on Scott's study. Conclusion: In patients with DMD aged five to 12 years the progression of the disease is delayed by steroids and the motor function is less reduced than muscular strength.

Key words: Duchenne muscular dystrophy, steroids, muscle strength, motor ability, MRC scale, Hammersmith motor ability score.

\section{Comparação da força e função motora em pacientes com distrofia muscular de} Duchenne com ou sem corticoterapia
\end{abstract}

\section{RESUMO}

Objetivo: Comparar força muscular e função motora de pacientes com distrofia muscular de Duchenne (DMD) em corticoterapia com a evolução natural da doença descrita por Scott et al. Método: Noventa pacientes, entre 5 e 12 anos de idade, em corticoterapia por um até sete anos, foram avaliados quanto à força muscular (FM) (escala MRC) e função motora (Hammersmith motor ability score). A relação entre idade, FM e função motora e a comparação com o estudo de Scott et al foram determinadas estatisticamente. Resultados: a relação idade/escore Hammersmith diminuiu 0,76 pontos a cada ano de aumento da idade (2,23 pontos na história natural). A relação idade/MRC decresceu 0,80 pontos a cada ano de aumento da idade (3,65 pontos na história natural). Conclusão: Nos pacientes em corticoterapia, a progressão da doença é mais lenta que na evolução natural em todas as faixas etárias avaliadas, sendo a FM mais comprometida que a função motora.

\section{Correspondence}

Samara Lamounier Santana Parreira Rua Caraíbas 0122 - lote 5/7 n० 93 - casa 4 - Setor Santa Genoveva 74672-500 Goiânia GO - Brasil

E-mail: samaralsparreira@ibest.com.br

Received 8 January 2010 Received in final form 8 March 2009 Accepted 22 March 2010

Palavras-chave: distrofia muscular de Duchenne, corticoterapia, força muscular, habilidade motora, escala Medical Research Council (MRC), Hammersmith motor ability score.

Duchenne muscular dystrophy (DMD) is an $\mathrm{X}$-linked disease caused by a mutation in the dystrophin gene (locus Xp21.2) that affects one in 3600-6000 live male births ${ }^{3}$. It has a progressive course that leads to the necessity of wheelchair around

Department of Neurology, Faculdade de Medicina da Universidade de São Paulo, São Paulo SP, Brazil. 
10-12 years of age and in addition to the severe proximal muscle involvement it also presents with restrictive respiratory insufficiency and myocardiopathy. The mean age at death that until 30-40 years ago was around 19,6 years of age, is increasing progressively due to the earlier diagnosis allowed by the molecular and immunohistochemical methods as well as by the improvement of the multidisciplinary management mainly represented by steroid therapy, cardiac and respiratory support, rehabilitation and orthopedic procedures, and psychosocial assistance. Presently, the life expectancy is around 30 years of age ${ }^{4}$ and it has been commented that the newly diagnosed patients are supposed to survive into their fourth decade with a reasonable quality of life ${ }^{5}$.

Steroids, although palliative, are the only pharmacological approach that acts in slowing the progressive loss of muscle strength and motor ability in patients with DMD. They also delay the restrictive respiratory insufficiency, the scoliosis and in a lesser extent the cardiac involvement ${ }^{3,6-9}$.

Most of the studies on steroids therapy have emphasized its effect in prolonging ambulation ${ }^{3}$ but the amount and duration of the improvement in strength and motor ability have not been scored in details. Before the general use of steroids for DMD, Scott et al. $(1982)^{10}$ established a profile of the natural progression of DMD which could serve as a reference base for the assessment of cases at varying ages and their response to therapy. They followed sequentially 61 boys with DMD for three years applying five different methods of motor and functional evaluation; the total muscle strength and the motor ability score were quantitatively determined using respectively the 6-point Medical Research Council Scale (MRC) grading and the functional scale based on 20 consecutive motor activities $^{11}$. The result of the follow-up showed progressive decline of muscle strength with age, a close correlation of total strength and the motor ability score, and a curvilinear relation of muscle strength with walking time over 28 and 150 feet. Therefore the objective of the present study was to evaluate the effect of the steroid therapy on the scores of muscle strength and motor ability measured in DMD patients with different times of treatment and to compare them with those reported by Scott et al in their description of the natural course of the disease.

\section{METHOD}

Ninety patients aged 5 to 12 years diagnosed with DMD by molecular analysis or immunohistochemistry and Western blotting for dystrophin on muscular biopsy sample, were assessed by a physiotherapist for quantifying muscular strength and motor ability applying the Medical Research Council Scale (MRC) and Hammersmith motor ability score, respectively. All patients received steroid therapy with deflazacort $(0.9 \mathrm{mg} / \mathrm{Kg} /$ day $)$ or pred-
Table 1. Sample characteristics according to age and steroid therapy.

\begin{tabular}{lc}
\hline Sample size $(\mathrm{N})$ & 90 \\
Age in years at the beginning of steroid therapy & \\
$\quad$ Mean \pm standard deviation (years) & $7.6 \pm 1.6$ \\
Minimum-Maximum & $4.1-10.9$ \\
Age in years at testing & \\
$\quad$ Mean \pm standard deviation (years) & $9.3 \pm 1.6$ \\
Minimum-Maximum & $5.3-11.9$ \\
Duration of treatment (years) & \\
Medium (Q1-Q3) & $1.1(1.0-2.2)$ \\
$\quad$ Minimum-Maximum & $0.8-6.8$ \\
Type of steroid & \\
Deflazacort & $58(64.4 \%)$ \\
Prednisolone & $32(35.6 \%)$ \\
\hline
\end{tabular}

nisolone $(0.75 \mathrm{mg} / \mathrm{kg} /$ day in an intermittent course of 10 days on, followed by 10 days off the drug) for a period varying from at least one to seven years (Table 1). No patients had been ever submitted to orthopedic surgical procedure and had ever interrupted the steroid intake. From October 2006 to February 2009 each patient was assessed only once by the same physiotherapist. The patients were evaluated in an unique opportunity by using the Hammersmith motor ability score which includes 20 items scored from 0 to 40, and the Medical Research Council for testing the muscular strength which 30 muscular groups, scored from 0 to 5 points ${ }^{10-12}$.

A concordance test was carried out through the participation of a second physiotherapist for 80 patients and concordance was statistically good or very good. This study was approved by the Ethical Committee for research projects analysis of our Institution under the number 0090/07, and all the parents of the 90 patients gave their informed consent.

For statistic analysis, the Pearson linear correlation (CI 95\%) was used to compare the age at evaluation with the scores of Hammersmith motor ability and MRC. The results of the present study were compared to the results of the Scott' study using a linear regression model with a confidence interval of the $95 \%$.

\section{RESULTS}

The relation between the patient's age at evaluation and the Hammersmith score in our study and that of Scott et al is shown in Fig 1. In the latter for each year of age increase the Hammersmith score showed a decrease of 2.23 points while in our study the decrease was of 0.76 . In our study the relation between the age at evaluation and the Hammersmith score did not present a statistically significant difference $(\mathrm{p}=0.079)$. 


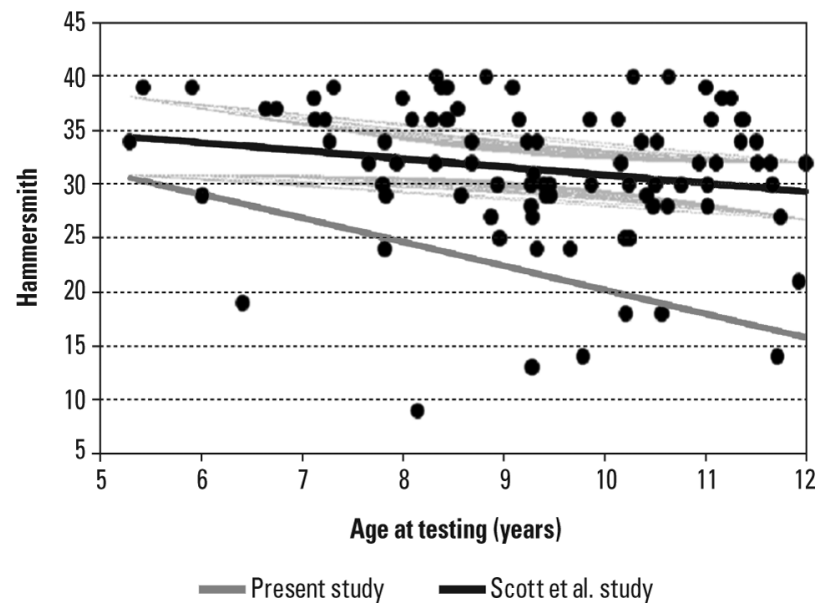

Fig 1. Scatter plot of the relation between Hammersmith scores and patient's age at testing in both studies.

Comparing our data with those of Scott et al. using Pearson's coefficient of correlation we observed that the loss of motor function in relation to the age in our patients was lesser than in Scott's patients with statistical significance, therefore confirming that the boys treated with steroids had a slower disease progression (Table 2). The Table 3 shows that the difference between the two studies is directly related to the increase of the age.

The relation between the patient's age at evaluation and the MRC index in the two studies is demonstrated in Fig 2 in which it is possible to observe that in the study of Scott et al for each year of increase of the age at evaluation there was a decrease of 3.65 in the MRC index; however in our patients we observed a decrease of 0.80 and the relation between the patient's age and the MRC index was statistically significant ( $\mathrm{p}=0.002)$.

Comparing our data with those of Scott et al using Pearson's coefficient of correlation we observed that in our patients the loss of muscular strength in relation to the age was lesser than in Scott's patients with statistical significance, therefore confirming that the boys treated with steroids had a slower disease progression (Table 4). The Table 5 shows that the difference between the two casuistics is directly related to the increase of the age.

The Fig 3 shows, as it is illustrated by dispersion

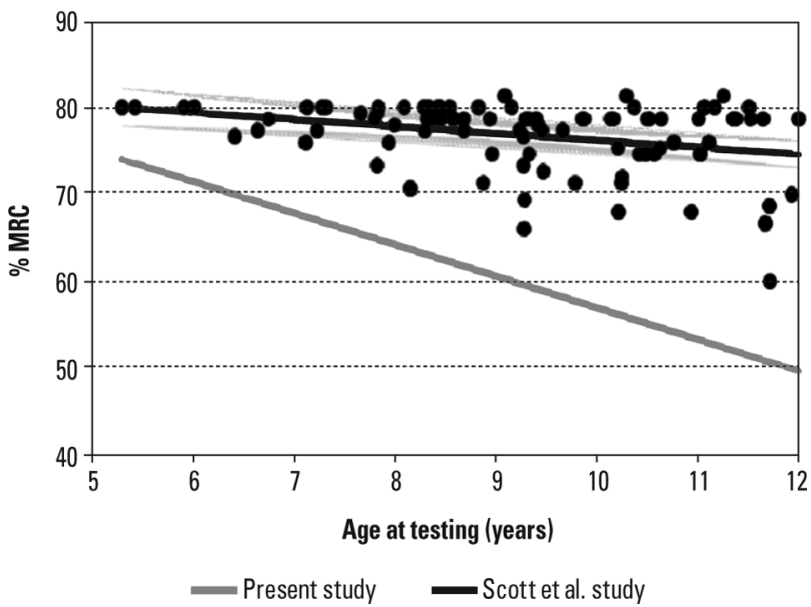

Fig 2. Scatter plot of the relation between MRC index and age at testing in both studies.

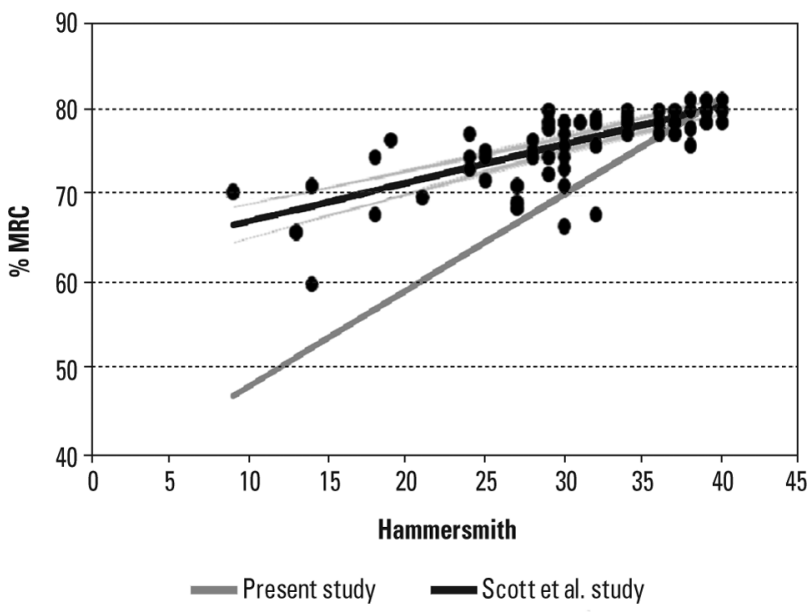

Fig 3. Scatter plot of the relation between Hammersmith scores and MRC index in both studies.

graphic, the relation between Hammersmith score and MRC index. In both studies it is possible to observe that the increase of MRC index and the Hammersmith score was directly related. However in the study of Scott et al., there was an increase of 1.1 in MRC index while in our study for each point of increase in Hammersmith score there was an increase of 0.45 in MRC index. The same

Table 2. Results of model for multiple regression for the adjusted relation between Hammersmith' scores and patient's age at testing in both studies.

\begin{tabular}{lcc}
\hline & Present study & Scott et al. study \\
\hline Regression model equation & $\mathrm{y}=38.5-0.76 \times$ & $\mathrm{y}=42.5-2.23 \times$ \\
Coefficient of correlation & $r=-0.19$ & $r=-0.63$ \\
$95 \%$ Confidence Interval $(\mathrm{Cl})$ & {$[-0.35 ;-0.01]$} & {$[-0.74 ;-0.48]$} \\
Sample size $(\mathrm{N})$ & 90 & 61 \\
\hline
\end{tabular}


Table 3. Comparison between adjusted means of Hammersmith scores according to patient's age at testing and comparison of the percentage difference of Hammersmith' scores in both studies.

\begin{tabular}{cccc} 
& \multicolumn{3}{c}{ Hammersmith' scores } \\
\cline { 2 - 4 } Age at testing & Present study & Scott et al. study & $\begin{array}{c}\text { Difference percentage } \\
\text { Present/Scott et al. }\end{array}$ \\
\hline 5 years & 34.7 & 31.4 & $10.5 \%$ \\
6 years & 33.9 & 29.1 & $16.5 \%$ \\
7 years & 33.2 & 26.9 & $23.4 \%$ \\
8 years & 32.4 & 24.7 & $31.2 \%$ \\
9 years & 31.6 & 22.4 & $41.1 \%$ \\
10 years & 30.9 & 20.2 & $53.0 \%$ \\
11 years & 30.1 & 18.0 & $67.2 \%$ \\
\hline
\end{tabular}

Table 4. Results of model for multiple regression for the adjusted relation between MRC index and patient's age at testing in both studies.

\begin{tabular}{lcc}
\hline & Present study & Scott et al. study \\
\hline Regression model & zy $84.2-0.80 \times$ & $\mathrm{y}=93.4-3.65 \times$ \\
Coefficient of correlation & $r=-0.32$ & $r=-0.77$ \\
$\quad 95 \%$ Confidence interval $(\mathrm{Cl})$ & {$[-0.47 ;-0.16]$} & {$[-0.85 ;-0.67]$} \\
Sample size $(\mathrm{N})$ & 90 & 61 \\
\hline
\end{tabular}

Table 5. Comparison between adjusted values according to age at testing and comparison of the percentage difference of MRC index in both studies.

\begin{tabular}{cccc} 
& \multicolumn{3}{c}{ MRC values } \\
\cline { 2 - 4 } Age at testing & Present study & Scott et al. study & $\begin{array}{c}\text { Difference percentage } \\
\text { Present/ Scott et al. }\end{array}$ \\
\hline 5 years & 80.2 & 75.2 & $6.6 \%$ \\
6 years & 79.4 & 71.5 & $11.0 \%$ \\
7 years & 78.6 & 67.9 & $15.8 \%$ \\
8 years & 77.8 & 64.2 & $21.2 \%$ \\
9 years & 77 & 60.6 & $27.1 \%$ \\
10 years & 76.2 & 56.9 & $33.9 \%$ \\
11 years & 75.4 & 53.3 & $41.5 \%$ \\
\hline
\end{tabular}

MRC: Medical Research Council Scale.

Table 6. Results of model for regression for the adjusted relation between MRC index and the Hammersmith' scores in both studies.

\begin{tabular}{lcc}
\hline & Present study & Scott et al. study \\
\hline Regression model & $\mathrm{y}=62.8+0.45 \times$ & $\mathrm{y}=93.4+3.65 \times$ \\
Coefficient of correlation & $\mathrm{r}=0.73$ & $\mathrm{r}=0.83$ \\
$95 \%$ Confidence Interval $(\mathrm{Cl})$ & {$[0.64 ; 0.80]$} & {$[0.75 ; 0.89]$} \\
Sample size $(\mathrm{N})$ & 90 & 61 \\
\hline
\end{tabular}

MRC: Medical Research Council Scale. 
relation was maintained concerning the loss of muscular strength and motor function, therefore suggesting that the steroid therapy has a greater beneficial influence on motor function than on motor strength.

Comparing our data with those of Scott et al. using Pearson's coefficient of correlation we observed that the correlation between muscular strength and motor function was lower in our study than in the study of Scott et al.; however, we did not observe a statistical significance (Table 6).

\section{DISCUSSION}

As it has been widely demonstrated in the literature ${ }^{13-19}$ our study confirmed the beneficial effect of steroid therapy in slowing the progression of DMD. According to Bushby et al., it strongly urges to consider glucocorticoid therapy in all patients who have $\mathrm{DMD}^{3}$. Our study evaluated an expressive number of patients all under steroid therapy.

According to the study of Scott et al. that had the prurpose of being a model for comparing the natural course of DMD against any changement of the course that could be promoved by any therapeutic resource, we compared in our study the relation between the age at the evaluation of the patient treated by steroids and Hammersmith score. We observed that the decrease of the scores that occurred accompanying the increase of the patients' age was lesser than that reported by Scott et al., as well as the loss of motor function whose difference with that reported in the natural course of DMD had statistical significance ${ }^{20}$.

Although our oldest patients have received lower scores that the youngest ones, the decrease of Hammersmith score did not present statistical significance. Based in this result we confirmed that concerning the motor function the disease progression in the treated patients is slower than that observed along the natural course and also that the Hammersmith scores show a stabilization along the different ages. For all ages the comparison between Hammersmith scores showed that our patients obtained greater scores than those of the patients from Scott et al. and that the difference increases along the increase of the patients' age. This finding is probably due to the fact that in the youngest boys the signs and symptoms of the disease are less evident and along the time the difference between non treated and treated patients become more evident.

The comparison between the patient's age at evaluation and the values of MRC índex showed an inverse relation, i.e., the muscular strength decreases progressively along the child's growth. The statistical analysis demonstrated that the loss of muscular force in relation to the increase of the age was lesser in our patients than in those of Scott et al. For all periods of age considered the values of the MRC index obtained was superior to that obtained by the patients of Scott et al., and as greater the age was, as greater was the difference between the two studies. Again, this finding is probably due to the quicker and greater deterioration of the clinical status in the non treated patients.

In both studies the correlation between Hammersmith scores and the values of MRC índex was strongly positive, therefore indicating that the motor function depends on the muscular strength. However in our study the motor function was less dependent on muscular strength than in the study of Scott et al., according to the results already exposed demonstrating that in the patients of different ages, the Hammersmith scores were less variable than the values of MRC index, in addition to the fact that for both tests the values were always superior to those described by Scott et al. According to Scott and Mawson, the correlation between motor strenght and function must be carefully analysed because although both measures have to be considered related, they are not directly dependent due to the occurrence of a variety of possible dynamic compensations ${ }^{21}$. This finding has been observed in our study that demonstrated a quicker decrease of the MRC index in relation to the decrease of the functional score. This much better performance of motor function in relation to the muscular strength has also been emphasized by Kinali et al., in six patients initially evaluated with less than five years of age and followed-up for 30 months and more than five years of steroid therapy ${ }^{22}$.

In conclusion our study of 90 patients with DMD demonstrated that the loss of muscular strength and motor function is slower in DMD patients under steroid therapy than along the natural course of the illness; in addition the loss of muscular strength is greater than the loss of motor function.

\section{REFERENCES}

1. Koenig M, Monaco AP, Kunkel LM. The complete sequence of dystrophin predicts a rod-shaped cytoskeletal protein. Cell 1988;53:219-228.

2. Hoffman EP, Monaco AP, Feener CC, Kunkel LM. Conservation of the Duchenne muscular dystrophy gene in mice and humans. Science 1987; 238:347-350.

3. Bushby K, Finkel R, Birnkrant DJ. Diagnosis and management of Duchenne muscular dystrophy, part 2: implementation of multidisciplinary care. The Lancet[Internet].2009,November 30. Avaliable from: www.thelancet.com/ neurology.

4. Eagle M, Baudouin SV, Chandler C, Giddings DR, Bullock R, Bushby K. Survival in Duchenne muscular dystrophy: improvements in life expectancy since 1967 and the impact of home nocturnal ventilation. Neuromuscul Disord 2002;12:926-929.

5. Wagner R, Lechtzin N, Judge DP. Current treatment of adult Duchenne muscular dystrophy. Biochimica et Biophysica 2007;1772: 229-237.

6. Manzur AY, Kuntzer T, Pike M, Swan A. Glucocorticoid corticosteroids for Duchenne muscular dystrophy. Cochrane Database Syst Rev 2008;1: CD003725.

7. Bushby K, Griggs R, MSG/ENMC FOR DMD trial study group. $145^{\text {th }}$ ENMC International Workshop: planning for an international trial of steroid dosage regimes in DMD (FOR DMD), 22-24 $4^{\text {th }}$ October 2006, Naarden, The Netherlands. Neuromuscul Disord 2007;17:423-428.

8. Angelini C. The role of corticosteroids in muscular dystrophy: a critical appraisal. Muscle Nerve 2007;36:424-435.

9. Biggar WD, Harris VA, Eliasoph L, Alman B. Long-term benefi ts of defl azacort treatment for boys with Duchenne muscular dystrophy in their second decade. Neuromuscul Disord 2006;16:249-255. 
10. Scott OM, Goddard C, Dubowitz V. Quantitation of muscle function in children: a prospective study in Duchenne muscular dystrophy. Muscle Nerve 1982;5:291-301.

11. Medical Reseach Concil. Aids to the Investigation of peripheral nerve injuries. London, England: Her Majesty's Stationery Office. 1976.

12. Parreira SLS. Quantification of muscle strength and motor ability in patients with Duchenne muscular dystrophy on steroid therapy. Arq Neuropsiquiatr 2007;65:245-250.

13. Mendell JR, Moxley RT, Griggs RC. Randomized double-blind six month trial of prednisone in Duchenne muscular dystrophy. N Engl J Med 1989;320:15921597.

14. Fenichel GM, Mendel JR, Moxley RT, et al. A comparison of daily and alternate-day prednisone therapy in the treatment of Duchenne muscular dystrophy. Arch Neurol 1991;48:575-579.

15. Griggs RC, Moxley RT, Mendell JR, et al. Duchenne distrophy. Randomized controlled trial of prednisone (18 months) and azathioprine. Neurology 1993; 93:520-527.

16. Biggar WD, Harris VA, Eliasoph L, Alman B. Long-term benefits of deflazacort treatment for boys with Duchenne muscular dystrophy in their second decade. Neuromuscul Disord 2006;16:249-255.

17. Biggar WD, Politano L, Harris VA, et al. Deflazacort in Duchenne muscular dystrophy: a comparison of two different protocols. Neuromuscul Disord 2004; 14:476-482.

18. Biggar WD, Gingas M, Flebings DL, Harris VA, Steele CA. Deflazacort treatment of Duchenne muscular dystrophy. J Ped 2001;138:45-50.

19. Pradhan S, Ghosh D, Srivastava NK, Mittal B, Pandey CM, Singh U. Prednisolone in Duchenne muscular dystrophy with imminent loss of ambulate. J Neurol 2006;253:1309-1316.

20. Altman DG. Practical statistics for medical research. London: Chapman and Hall,1991.

21. Scott E, Mawson SJ. Measurement in Duchenne muscular dystrophy: considerations in the development of a neuromuscular assesment tool. Dev Med Child Neurol 2006; 48:540-544.

22. Kinali M, Mercuri E, Main M, Muntoni F, Dubowitz V. An effective, low-dosage, intermittent schedule of prednisolone in the long-term treatment of early cases of Duchenne dystrophy. Neuromuscul Disord 2002;12(Suppl 1):S169-S174. 